\title{
FAKTOR-FAKTOR PERCERAIAN PADA MASYARAKAT MUSLIM KOTA \\ PALU (ANALISIS SOSIOLOGIS)
}

Sitti Nurkhaerah dan Hamiyuddin ${ }^{1}$

Fakultas Syariah IAIN Palu

Email:nurkhaerah@iainpalu.ac.id

\begin{abstract}
The phenomenon of divorce is also inseparable from various causes, so that it becomes the reason for husband or wife to file for divorce at the religious court. In addition, the impact of divorce will have a major influence on the psychology of parties, the environment and the children are no exception. Specifically in Central Sulawesi, the number of divorces that occurred during 2016 was 2,699 cases handled by the Religious Courts in 13 districts and cities. This figure has increased when compared to 2015 only 2,490 cases. In addition, from this overall figure, it is noted that wives dominate filing for divorce compared to husbands Keywords: Divorce, Muslim Society, Religious Court
\end{abstract}

\begin{abstract}
Abstrak
Fenomena perceraian pun tidak terlepas dari berbagai macam faktor penyebab, sehingga menjadi alasan suami atau istri untuk mengajukan perceraian pada pengadilan agama. Selain itu, dampak dari terjadinya perceraian akan memberikan pengaruh yang besar terhadap psikologi pihak, lingkungan dan tidak terkecuali pula kepada anak. Khusus di Sulawesi Tengah, angka perceraian yang terjadi selama tahun 2016, sebanyak 2.699 kasus yang ditangani oleh Pengadilan Agama di 13 kabupaten dan kota. Angka tersebut mengalami kenaikan jika dibandingkan dengan tahun 2015 hanya 2.490 kasus. Selain itu, dari keseluruhan angka tersebut tercatat istri yang mendominasi melakukan pengajuan cerai dibandingkan suami

Katakunci: Perceraian, Masyarakat Muslim, Pengadilan Agama
\end{abstract}

A. Pendahuluan

Pernikahan adalah sebagai fitrah ${ }^{2}$ merupakan nikmat Allah atas hambaNya dalam kehidupan di dunia ini. Jika tanpa adanya kesenangan yang menunjang, maka akan terasa gersang. Apabila direnungkan lebih jauh, bahwa kecendurungan (watak) tersebut mampu membebaskan manusia dari segala

\footnotetext{
${ }^{1}$ Penulis merupakan Dosen tetap pada Fakultas Syariah Institut Agama Islam Negeri Palu

${ }^{2}$ M. Quaraish Shihab, Pengantin Al-Qur'an Kalung Permata Buat Anak-anakku, (Cet. VI; Jakarta: Lentera Hati, 2007), h. 55.
} 
belenggu kenistaan, tentunya jika diarahkan pada yang di Ridhai Allah. Hal ini bukanlah merupakan tujuan utama. Karena semuanya itu hanyalah sebagai mediator di dalam mencapai tujuan yang lebih mulia. Sebab cabang yang bagus tentu berasal dari pondasi (akar) yang bagus pula. ${ }^{3}$ Demikian pula dengan kehidupan rumah tangga. Allah swt. berfirman dalam Q.S. al-Ruum/30: 21.

Dan di antara tanda-tanda (kebesaran)-Nya ialah Dia menciptakan pasanganpasangan untukmu dari jenismu sendiri, agar kamu cenderung dan merasa tenteram kepadanya, dan dijadikan-Nya diantaramu rasa kasih dan sayang. Sunggu, pada yang demikian itu benar-benar terdapat tanda-tanda (kebesaran Allah) bagi kaum yang berfikir. ${ }^{4}$

Nikah adalah salah satu asas pokok hidup yang paling utama dalam pergaulan atau masyarakat yang sempurna. Pernikahan itu bukan saja merupakan satu jalan yang amat mulia untuk mengatur kehidupan rumah tangga dan keturunan, tetapi dapat juga dipandang sebagai suatu jalan menuju pintu perkenalan antara satu kaum dengan kaum yang lain, dan perkenalan itu menjadi suatu jalan untuk menyampaikan pertolongan antara yang satu dengan yang lainnya. $^{5}$

Adapun dalam hukum positif yang terdapat dalam Undang-undang RI Nomor 1 tahun 1974 tentang perkawinan pasal 1 disebutkan:

Perkawinan adalah ikatan lahir batin antara seorang pria dan seorang wanita sebagai suami isteri dengan tujuan membentuk keluarga atau rumah tangga yang bahagia dan kekal berdasarkan Ketuhanan Yang Maha Esa. ${ }^{6}$

${ }^{3}$ Muhammad Mahdi Al-Istanbūīi, Taḥfas al-A'rūs, terj. Ibnu Ibrahim, Kado Perkawinan, (Cet. I; t.t.: Pustaka Azzam, 1999), h. 3.

${ }^{4}$ Departemen Agama RI, Al-Qur'an Al-Karim dan Terjemahnya, (Semarang; PT. Karya Toha Putra Semarang, 2002), h. 572

${ }^{5}$ Sulaiman Rasyid, Fiqh Islam, (Cet. VII; Bandung: Sinar Baru Algensindo, 1994), h. 374.

${ }^{6}$ Republik Indonesia, “Undang-undang, Nomor. 1 Tahun 1974," tentang Perkawinan Pasal 1.h. 1. 
Namun, setiap rumah tangga memiliki berbagai permasalahan yang berujung kepada kedua belah pihak tidak mampu menyelesaikan maupun dari hakamain 7 Menangani masalah tersebut, Islam telah membuka kemungkinan untuk menempuh jalur perceraian baik dengan jalan talak atau melalui fasakh. Hal ini pun harus disadari sebagai jalan terbaik bagi kedua pihak karena memaksakan sebuah kebahagian hanya akan mendatangkan penderitaan. ${ }^{8}$ Tidak dapat dipungkiri dalam suatu keluarga berada dalam kondisi statis atau dalam keadaan seimbang, namun juga terkadang mengalami kegoncangan di dalamnya. ${ }^{9}$

Fenomena perceraian di Indonesia menuntut perhatian besar hal ini didasarkan bahwa kenaikan angka perceraian sejak tahun 2009-2016 sebesar 1620 persen. Bahkan menurut Badan Kependudukan dan Keluarga Berencana Nasional (BKKN) Indonesia menduduki peringkat tertinggi di Asia Pasifik dalam hal perceraian. ${ }^{10}$ Ditambahkan pula dari Republika bahwa perkara perceraian tampak terus meningkat setiap tahunnya kendati angka pernikahan relatif stabil. Sejak tahun 2012, kenaikan angka perceraian dibandingkan pernikahan per tahun terus mengalami kenaikan di atas satu persen. ${ }^{11}$ Fenomena di atas sangat mengkhawatirkan karena pihak yang bercerai akan menghasilkan paradigma negatif bagi masyarakat, apalagi bila sebahagian besar masyarakat menganggap kawin cerai termasuk hal yang lumrah.

\footnotetext{
${ }^{7}$ Hakamain adalah orang yang ditunjuk sebagai pihak penengah bagi keluarga yang bersengketa baik itu dari pihak suami ataupun dari pihak istri untuk berperan sebagai juru damai.

${ }^{8}$ Ali Yusuf As-Subki, Fiqh Keluarga Pedoman Berkeluarga Dalam Islam, Jakarta: Amzah, 2010, Cet 1, h. 330.

${ }^{9}$ Geogrge Ritzer, Teori Sosiologi Modern, (Cet. V; Jakarta: Kencana, 2008), h. 153.

${ }^{10}$ Dwi Purnawan, “Tingkat Percerain Termasuk yang Tertinggi di Dunia” 26 September 2016, http://www.gulalives.co/2016/09/26/tingkat-perceraian-di-indonesia-termasuk-yangtertinggi-di-dunia/, 15 Oktober 2017.

${ }^{11}$ Republika, “Tingkat Perceraian Mengkhawatirkan”, 3 Oktober 2016 http://www.republika.co.id/berita/koran/halaman-1/16/10/03/oegjc619-tingkat-perceraianmengkhawatirkan, 15 Oktober 2017.
} 
Khusus di Sulawesi Tengah, angka perceraian yang terjadi selama tahun 2016, sebanyak 2.699 kasus yang ditangani oleh Pengadilan Agama di 13 kabupaten dan kota. Angka tersebut mengalami kenaikan jika dibandingkan dengan tahun 2015 hanya 2.490 kasus. Selain itu, dari keseluruhan angka tersebut tercatat istri yang mendominasi melakukan pengajuan cerai dibandingkan suami. $^{12}$

Berdasarkan data yang diperoleh di Pengadilan Agama Klas IA Palu, terdapat 2.910 perkara talak yang diterima oleh Pengadilan Agama Klas IA Palu.

Tabel 1

Perkara yang Diterima pada Pengadilan Agama Palu Tahun 2013-2014

\begin{tabular}{|c|c|c|c|c|}
\hline \multirow[b]{2}{*}{ No } & \multirow[b]{2}{*}{ Tahun } & \multicolumn{2}{|c|}{ Jenis Perkara } & \multirow{2}{*}{$\begin{array}{c}\text { Jumlah } \\
\text { Perkara } \\
\text { yang } \\
\text { Diterima }\end{array}$} \\
\hline & & $\begin{array}{l}\text { Cerai } \\
\text { Talak }\end{array}$ & Cerai Gugat & \\
\hline 1 & 2013 & 175 & 466 & 641 \\
\hline 2 & 2014 & 195 & 534 & 729 \\
\hline 3 & 2015 & 192 & 547 & 739 \\
\hline 4 & 2016 & 230 & 571 & 801 \\
\hline \multicolumn{2}{|c|}{ Jumlah } & 792 & 2118 & 2.910 \\
\hline
\end{tabular}

Sumber: Pengadilan Agama Klas IA Palu, 2017

Data di atas menggambarkan bahwa dari tahun 2013-2014 jumlah perkara yang diterima bertambah dari tahun ke tahun. Pada tahun 2013, perkara yang diterima sebanyak 641 perkara, pada tahun 2014 sebanyak 729 perkara, pada tahun 2015 meningkat menjadi 739, dan pada tahun 2016 meningkat pesat sebesar 801 perkara. Selain itu, data di atas pula perkara perceraian lebih banyak diajukan oleh pihak istri yang dilatar belakangi oleh beberapa faktor.

\footnotetext{
${ }^{12}$ Republika, Angka Perceraian di Sulteng Capai 2.699 Kasus Selama 2016” 1 Februari 2017, http://nasional.republika.co.id/berita/nasional/daerah/17/02/01/okpa5x384-angkaperceraian-capai-2699-kasus-di-sulteng-selama-2016, 15 Oktober 2017.
} 
Adapun perkara yang diputus oleh Pengadilan Agama Klas IA Kota Palu sebanyak 2.611 perkara dengan rincian sebagai berikut:

Tabel 2

Perkara yang Diputus pada Pengadilan Agama Palu

\begin{tabular}{|r|c|r|r|r|}
\hline \multirow{2}{*}{ No } & \multirow{2}{*}{ Tahun } & \multicolumn{2}{|c|}{ Jenis Perkara } & Jumlah Perkara \\
\cline { 3 - 4 } & & $\begin{array}{l}\text { Cerai } \\
\text { Talak }\end{array}$ & Cerai Gugat & yang Diputus \\
\hline 1 & 2013 & 130 & 402 & 532 \\
\hline 2 & 2014 & 170 & 460 & 630 \\
\hline 3 & 2015 & 160 & 486 & 646 \\
\hline 4 & 2016 & 230 & 573 & 803 \\
\hline \multicolumn{2}{|c|}{ Jumlah } & 690 & 1.921 & 2.611 \\
\hline
\end{tabular}

Sumber: Pengadilan Agama Klas IA Palu, 2017

Tabel di atas menunjukkan bahwa jumlah perkara yang diputus pada rentan waktu tahun 2013-2014 adalah cerai talak sebanyak 690 perkara dan cerai gugat sebanyak 1.921. Jumlah perkara setiap tahunnya pun semakin meningkat. Peningkatan terbesar adalah pada pada tahun 2016 dengan jumlah perkara yang diputus sebanyak 573 perkara. Data di atas menunjukkan pula bahwa perkara yang diputus terbanyak adalah jenis perkara cerai gugat. Fenomena ini merupakan masalah serius dan membutuhkan langkah preventif dari pemerintah tekait, upaya yang telah dilakukan oleh pihak pengadilan adalah melalui mediasi akan tetapi memerlukan dukungan dan peran serta dari berbagai kalangan mengatasi masalah di atas.

Alasan peneliti memilih Kota Palu sebagai obyek penelitian karena melihat pola kehidupan masyarakat yang sangat heterogen, sehingga berbagai permasalahan dapat saja terjadi utamanya dalam lingkungan keluarga. Penduduk yang menetap di Kota Palu berasal dari berbagai suku bangsa seperti Bugis, 
Toraja, Gorontalo, Manado, Jawa, Arab, Tionghia, dan Kaili yang merupakan suku asli. ${ }^{13}$

Berdasarkan latar belakang di atas, maka penulis tertarik mengkajinya dengan judul "Faktor-faktor Perceraian pada Masyarakat Muslim Kota Palu (Analisis Sosiologis)". Hal yang memotivasi penulis menyangkut judul tersebut diharapkan mampu memberikan jawaban yang jelas tentang faktor dominan penyebab perceraian sehingga dapat menjadi bahan pertimbangan bagi pemerintah dan pihak terkait untuk menemukan solusi mengatasinya. Selain itu, sebagai sumbangsih terhadap ilmu pengetahuan utamanya dalam sosiologi perceraian.

Secara umum penelitian ini tersusun atas beberapa pebahasan yang terbagi medalam tiga bagian yaitu pendahuluan, isi, dan penutup. Penulis menyusunmenjadi baberapa bagian yang masing- masing memuat sub-sub pembahasan.

\section{B. Pembahasan}

\section{Tinjauan Umum tentang Perceraian}

a. Perceraian dalam Fikih Islam

Perceraian atau talak berasal dari kata itlaq," artinya melepas atau meninggalkan," dalam istilah agama "talaq" artinya melepaskan ikatan perkawinan atau bubarnya hubungan perkawinan."

Perceraian merupakan perbuatan yang tidak disukai, karena Akad nikah diadakan adalah untuk selamanya dan seterusnya hingga meninggal dunia, agar suami isteri sama-sama dapat mewujudkan rumah tangga tempat berlindung, menikmati naungan kasih sayang dan dapat memelihara anak-anaknya hidup dalam pertumbuhan yang baik. Sebagaimana firman Allah dalam Q.S. al-Nisa:

${ }^{13}$ Wikipedia, “Kota Palu” https://id.wikipedia.org/wiki/Kota_Palu, 16 Oktober 2017 
Bagaimana kamu akan mengambilnya kembali, padahal sebagian kamu telah bergaul satu sama lain (sebagai suami-isteri). Dan mereka (isteriisterimu) telah mengambil perjanjian yang kuat (ikatan pernikahan) dari kamu. $^{14}$

Muhammad Mustafa Tsalabī memberikan makna perkawinan dengan akad yang kuat antara seorang laki-laki dan seorang perempuan yang hidup bersama berdasarkan ketentuan syara sebagai ibadah kepada Allah. Esensi $n$ mengindikasikan bahwa perkawinan dalam Islam bukan hanya dilakukan untuk suatu waktu tertentu, akan tetapi diharapkan dapat dipertahankan untuk selamanya. ${ }^{15}$

Pemenuhan hak dan kewajiban suami isteri secara adil dan makruf dan mampu mewujudkan rumah tangga yang sakinah, mawadah, dan rahmah. Karena biasanya penyebab ketidaknyamanan rumah tangga dikarenakan tidak terpenuhinya hak dan kewajiban suami isteri secara adil dan makruf, baik hak dan kewajiban yang bersifat materil maupun hak dan kewajiban yang bersifat inmaterial. Bahwa kematangan emosional dari suami isteri juga ikut terpengaruh terhadap kenyamanan, keserasian, dan ketentaraman dalam rumah tangga. Dua hal inilah yang menjadi faktor utama penyebab terjadinya perperkaraan atau perselisihan yang mengarah pada putusnya perkawinan (perceraian). ${ }^{16}$

\section{Perceraian dalam Hukum Nasional}

Perceraian terjadi apabila kedua belah pihak baik suami maupun isteri sudah sama-sama merasakan ketidakcocokan dalam menjalani rumah tangga. Undang-undang Nomor 1 tahun 1974 tentang Perkawinan tidak memberikan definisi mengenai perceraian secara khusus. Pasal 39 ayat (2) Undang-undang RI Nomor 1 tahun 1974 tentang perkawinan serta penjelasannya menyatakan bahwa

\footnotetext{
${ }^{14}$ Departemen Agama RI., Al-Qur'an dan Terjemahnya (Cet. X; Bandung: CV. Diponegoro, 2006), h. 105

${ }^{15}$ Muhammad Mustafa Tsalabi, Ahkam al-Usrah fi al-Islam, (Beirut: Dar an-Nadah al'Arabiyah, 1997), h. 260.

${ }^{16}$ Syahrizal Abbas, Mediasi dalam Perspektif Hukum Syariah, Hukum Adat, dan Hukum Nasional (Cet. I; Jakarta: Pernada Media Group, 2009), h. 180-181.
} 
perceraian dapat dilakukan apabila sesuai dengan alasan-alasan yang telah ditentukan. Definisi perceraian di Pengadilan Agama, dilihat dari putusnya perkawinan dalam Undang-undang perkawinan dijelaskan, yaitu:

a. Karena kematian.

b. Karena perceraian.

c. Karena putusan Pengadilan. ${ }^{17}$

Pada penyebab perceraian, Pengadilan memberikan legal formal, yaitu pemberian surat sah atas permohonan talak dari suami. Surat talak tersebut diberikan dengan mengacu pada alasan-alasan sebagaimana diatur dalam pasal 39 ayat 2 Undang-undang RI Nomor 1 tahun 1974 tentang perkawinan salah satu pihak melanggar hak dan kewajiban. Sehingga, walaupun surat talak tersebut sah secara hukum, namun tidak ada kata kesepakatan di antara dua pihak untuk bercerai. Sebagai contoh apabila seorang suami menjatuhkan talak satu kepada isterinya, maka talak satu yang diucapkan tersebut harus dilegalkan telebih dahulu di depan Pengadilan. Karena pada dasarnya secara syar'i, talak tidak boleh diucapkan dalam keadaan emosi. Melalui proses legalisasi di depan Pengadilan, terdapat rentang waktu bagi suami untuk merenungkan kembali talak yang telah terucap.

Saat ini Pengadilan Agama memberikan sarana mediasi. ${ }^{18}$ Di Pengadilan sekarang sudah dimulai sejak adanya Surat Edaran dari Mahkamah Agung RI Nomor 01 tahun 2002. Seluruh hakim di Pengadilan Agama benar-benar harus mengoptimalkan lembaga mediasi tersebut kemudian di keluarkannya PERMA

\footnotetext{
${ }^{17}$ Undang-undang RI Nomor 1 tahun 1974 tentang Perkawinan pasal 39 ayat 2 , yang dilengkapai dengan Undang-undang R.I. Nomor. 23 Tahun 2004 Penghapusan Kekerasan dalam Rumah Tangga dan Kompilasi Hukum Islam, (Cet. I; WIPRESS Wacana Intelektual, 2007), h. 1112.

${ }^{18}$ Syahrizal Abbas, Mediasi dalam Perspektif Hukum Syariah, Hukum Adat, dan Hukum Nasional, h. 192-193
} 
RI Nomor 02 tahun 2003 jo PERMA RI Nomor 01 tahun 2008 tentang prosedur mediasi di Pengadilan.

Melalui mediasi tersebut, banyak permohonan talak yang ditolak oleh Pengadilan Agama, dengan beberapa alasan. Pertama, karena tidak sesuai dengan ketentuan Undang-undang. Kedua, positanya kabur, dan antara posita ${ }^{19}$ dan petitum ${ }^{20}$ nya bertentangan. Misalnya, isteri minta cerai, tetapi dia minta nafkah juga, dalam alasan perceraiannya, si isteri menyebutkan bahwa suaminya tidak memberi nafkah selama beberapa bulan berturut-turut. ${ }^{21}$

Tatacara pengajuan permohonan dan gugatan perceraian merujuk pada pasal 118 HIR, yaitu bisa secara tertulis maupun secara lisan. Apabila suami mengajukan permohonan talak, maka permohonan tersebut diajukan di tempat tinggal si isteri. Apabila isteri mengajukan gugatan cerai, gugatan tersebut juga diajukan ke Pengadilan tempat tinggal isteri, dalam hal ini, seorang isteri memang mendapatkan kemudahan sebagaimana diatur dalam hukum Islam. Setelah cerai, maka bagi isteri berlaku masa tunggu (masa iddah), yaitu selama tiga kali suci sekurang-kurangnya sembilan puluh hari. ${ }^{22}$ Bagi wanita yang sedang hamil, maka masa iddahnya adalah sampai dia melahirkan. ${ }^{23}$ Masa iddah tersebut berlaku ketika putusan hakim berkekuatan hukum tetap. Namun untuk kasus cerai talak, maka masa iddah berlaku setelah permohonan talak suami dilegalkan oleh Pengadilan Agama.

\section{Penerapan Nilai-nilai Sosial dalam Keluarga}

a. Fungsi dan sistem nilai

\footnotetext{
${ }^{19}$ Posita, merupakan penjelasan tentang keadaan dan penjelasan yang berhubungan dengan hukum yang dijadikan dasar atau alasan gugatan.

${ }^{20}$ Potitum, merupakan isi permintaan penyelesaian kepentingan pemohon dalam surat gugatannya.

${ }^{21}$ Syahrizal Abbas, Mediasi dalam Perspektif Hukum Syariah, Hukum Adat, dan Hukum Nasional, h. 2.

${ }^{22}$ Kompilasi Hukum Islam (KHI) Pasal 135 bagian (b).

${ }^{23}$ Kompilasi Hukum Islam (KHI) Pasal 135 bagian (c).
} 
Konsep nilai dalam kajian sosiologis melihat bahwa nila-inilai sosial seseorang atau kelompok secara langsung dapat mempengaruhi segala aktivitas, terutama dalam rangka menyesuaikan diri dengan norma-norma yang ada dalam masyarakat sekelilingnya. Nilai-nilai sosial dapat menentukan ukuran besar kecil atau tinggi rendahnya status dan peranan seseorang di tengah-tengah kehidupan masyarakat.

Nilai dapat diartikan sebagai harga (dalam arti taksiran harga), harga sesuatu (uang) misalnya jika diukur atau ditukarkan dengan yang lain, angka kepandaian, kadar (mutu, banyak sedikitnya isi), dan sifaf-sifat (hal-hal) yang penting atau berguna bagi kemanusiaan. Soekanto mengemukakan bahwa nilai merupakan pandangan-pandangan mengenai apa yang baik dan apa yang yang buruk, karena itu yang baik harus di taati dan yang buruk harus dihindari. ${ }^{24}$

Nilai juga merupakan sesuatu yang abstrak yang dijadikan pedoman serta prinsip-prinsip umum dalam bertindak dan bertingkah laku. Keterikatan orang atau kelompok terhadap nilai sangat relatif dan kuat dan bahkan bersifat emosional. Oleh sebab itu nilai dapat dilihat sebagai pedoman bertindak dan sekaligus tujuan kehidupan manusia itu sendiri. Sehingga dapat dalam ciri dari nilai sosial yang dikenal yakni:

1) Nilai merupakan konstruksi masyarakat yang tercipta melalui interaksi diantara para anggota masyarakat. Nilai tercipta secara sosial, bukan secara biologis atau bawaan sejak lahir;

2) Nilai sosial ditularkan, yakni nilai dapat diteruskan dan ditularkan dari satu grup ke grup yang lain dalam suatu masyarakat melalui berbagai macam

${ }^{24}$ Soejono Soekanto, Sosiologi Keluarga (Tentang Ikhwal Keluarga, Remaja dan Anak), (Jakarta; Rineka Cipta, 2004), h. 9 
proses sosial dan dari satu masyarakat serta dari nkebudayaan ke yang lainnya melalui akulturasi, difusi, dan sebagainya;

3) Nilai dapat dipelajari. Artinya nilai dicapai dan bukan bawaan lahir. Proses pencapaian nilai-nilai itu dimulai sejak masa kanak-kanak dalam keluarga melalui sosialisasi;

4) Nilai memuaskan manusia dan mengambil bagian dalam usaha pemenuhan kebutuhan-kebutuhan sosial. Nilai yang disetujui dan yang telah diterima secara sosial itu menjadi dasar bagi tindakan dan tingkah laku, baik secara pribadi atau grup dan masyarakat secara keseluruhan. Nilai juga membantu masyarakat agar dapat berfungsi dengan baik. Tanpa suatu sistem nilai, masyarakat akan menjadikacau. Oleh karena itu, sistem nilai sosial dipandang penting oleh masyarakat, khususnya untuk pemeliharaankemakmuran dan kepuasan sosial bersama;

5) Nilai merupakan asumsi-asumsi abstrak dimana terdapat konsensus sosial tentang harga relatif dari objek dalam masyarakat. Nilai-nilai secara konseptual merupakan abstraksi dari unsur-unsur nilai dan bermacammacamobyek di dalam masyarakat;

6) Nilai cenderung berkaitan satu dengan yang lainnya secara komunal untuk membentuk pola-pola dan sistem nilai dalam masyarakat. Bila tidak terdapat keharmonisan yang integral dari niali-nilai sosial, maka akan timbul problem sosial;

7) Sistem-sistem nilai bervariasi antar kebudayaan satu dengan kebudayaan yang lain, sesuai dengan harga relatif yang diperlihatkan oleh setiap kebudayaan terhadap polapola aktivitas dan tujuan serta sasarannya. Dengan kata lain, keanekaragaman kebudayaan dengan bentuk dan fungsi yang saling berbeda menghasilkan sistem-sistemnilai yang saling berbeda pula. 
Batasan nilai dapat mengacu pada berbagai hal, seperti minat,kesukaan, pilihan, tugas, kewajiban agama, kebutuhan, keamanan,hasrat, keengganan, daya tarik dan hal-hal yang lain yang berhubungan dengan perasaan dari orientasi seleksi. Seseorang dalam melaksanakan sesuatu terlebih dahulu mempertimbangkan nilai. Dengan kata lain mempertimbangkan untuk mengadakan pilihan tentang nilai baik dan buruk adalah suatu keharusan. Jika seseorang tidak melakukan pilihannya tentang nilai, maka orang lain atau kekuatan luar akan menetapkan pilihan nilai untuk dirinya.

\section{A. Gambaran Perceraian pada Masyarakat Muslim Kota Palu}

Kota Palu sebagai ibukota Provinsi Sulawesi Tengah merupakan kota yang masyarakatnya majemuk dan dimungkinkan tingkat perceraian dapat terjadi. Hal ini disebabkan karena masyarakat yang majemuk dan memiliki latar belakang yang berbeda sehingga akan muncul kepribadian yang berbeda. Adapun gambaran tingkat perceraian.

Berdasarkan data yang diperoleh di Pengadilan Agama Klas IA Palu, terdapat 2.910 perkara talak yang diterima oleh Pengadilan Agama Klas IA Palu.

Tabel 1.4

Perkara yang Diterima pada Pengadilan Agama Palu

\begin{tabular}{|r|r|r|r|r|}
\hline \multirow{2}{*}{ No } & \multirow{2}{*}{ Tahun } & \multicolumn{2}{|c|}{ Jahun 2013-2016 } & \multirow{2}{*}{$\begin{array}{c}\text { Jumlah } \\
\text { Perkara } \\
\text { yang } \\
\text { Diterima }\end{array}$} \\
\cline { 3 - 4 } & $\begin{array}{c}\text { Cerai } \\
\text { Talak }\end{array}$ & Cerai Gugat & 641 \\
\hline 1 & 2013 & 175 & 466 & 729 \\
\hline 2 & 2014 & 195 & 534 & 739 \\
\hline 3 & 2015 & 192 & 547 & 801 \\
\hline 4 & 2016 & 230 & 571 & 2.910 \\
\hline \multicolumn{2}{|c|}{ Jumlah } & 792 & 2118 & \\
\hline
\end{tabular}

Sumber: Pengadilan Agama Klas IA Palu, 2017

Data di atas menggambarkan bahwa dari tahun 2013-2016 jumlah jenis perkara dan jumlah perkara yang diterima secara umum mengalami peningkatan. 
Jenis perkara cerai talak yang diterima pada Pengadilan Agama Klas I A pada tahun 2013 berjumlah 175 perkara, kemudian pada tahun berikutnya yaitu pada tahun 2014 mengalami kenaikan sebesar 195 perkara atau kenaikan terjadi sebesar $11,43 \%$ dari tahun sebelumnya. Kemudian pada tahun 2015 mengalami penurunan dari tahun sebelumnya sebesar 192 perkara atau mengalami penurunan sebesar 1,53\% dari tahun sebelumnya. Namun pada tahun 2016, terjadi kenaikan dari tahun sebelumnya sebesar 230 perkara atau mengalami kenaikan dari tahun sebelumnya sebesar 19,79\%. Adapun jumlah perkara yang diterima oleh Pengadilan Agama Klas I A dari jenis perkara cerai talak dalam rentang waktu 2013-2016 sebesar 792 perkara.

Adapun jenis perkara cerai gugat yang diterima oleh Pengadilan Agama Klas I A Palu pada tahun 2013 sebesar 466\ perkara. Kemudian pada tahun 2014 mengalami kenaikan sebesar 534 perkara atau mengalami kenaikan dari tahun sebelumnya sebesar $14,59 \%$. Kemudian pada tahun berikutnya yaitu tahun 2015 kembali mengalami kenaikan sebesar 547 perkara atau kenaikan terjadi hingga 2,43\% dari tahun sebelumnya.Selanjutnya pada tahun 2016 kembali mengalami kenaikan sebesar 571 perkara yang diterima atau kenaikan terjadi hingga 4,39\% dari tahun sebelumnya. Adapun jumlah perkara cerai gugat yang diterima oleh Pengadilan Agama Klas I A rentang waktu 2013-2016 sebesar 2.118 perkara.

Adapun jumlah perkara yang diterima secara keseluruhan baik dari jenis perkara cerai gugat dan cerai talak yang diterima oleh Pengadilan Agama Klas I A Palu pada tahun 2013 berjumlah 641 perkara. Kemudian pada tahun berikutnya pada tahun 2014 mengalami kenaikan sebesar 729 perkara atau naik sebesar $13,73 \%$ dari tahun sebelumnya. Pada tahun selanjutnya yaitu 2015 kembali mengalami kenaikan sebesar 739 perkara atau naik sebesar 1,37\% dari tahun sebelumnya. Kemudian pada tahun 2016 kembali mengalami kenaikan dengan 
jumlah 801 perkara atau naik sebesar 8,39\% dari tahun sebelumnya. Adapun jumlah keseruhan total jumlah perkara yang diterima oleh Pengadilan Agama Klas I A Palu baik jenis perkara cerai gugat dan cerai talak rentang waktu 2013-2016 sebesar 2.910 perkara. Secara umum dapat disimpulkan pula bahwa cerai gugat adalah perkara yang paling dominan diterima oleh Pengadilan Agama Klas IA Palu.

Adapun perkara yang diputus oleh Pengadilan Agama Klas IA Kota Palu sebanyak 2.611 perkara dengan rincian sebagai berikut:

Tabel 2.4

Perkara yang Diputus pada Pengadilan Agama Palu

\begin{tabular}{|c|c|c|c|c|}
\hline \multirow[b]{2}{*}{ No } & \multirow[b]{2}{*}{ Tahun } & \multicolumn{2}{|c|}{ Jenis Perkara } & \multirow{2}{*}{$\begin{array}{c}\text { Jumlah Perkara } \\
\text { yang Diputus }\end{array}$} \\
\hline & & $\begin{array}{l}\text { Cerai } \\
\text { Talak }\end{array}$ & Cerai Gugat & \\
\hline 1 & 2013 & 130 & 402 & 532 \\
\hline 2 & 2014 & 170 & 460 & 630 \\
\hline 3 & 2015 & 160 & 486 & 646 \\
\hline 4 & 2016 & 230 & 573 & 803 \\
\hline \multicolumn{2}{|c|}{ Jumlah } & 690 & 1.921 & 2.611 \\
\hline
\end{tabular}

Sumber: Pengadilan Agama Klas IA Palu, 2017

Data di atas menggambarkan bahwa dari tahun 2013-2016 jumlah jenis perkara dan jumlah perkara yang yang telah diputus pada Pengadilan Agama Klas IA Palu secara umum mengalami peningkatan. Jenis perkara cerai talak yang telah diputus pada tahun 2013 berjumlah 130 perkara, kemudian pada tahun berikutnya yaitu pada tahun 2014 mengalami kenaikan sebesar 170 perkara atau kenaikan terjadi sebesar $30,77 \%$ dari tahun sebelumnya. Kemudian pada tahun 2015 mengalami penurunan dari tahun sebelumnya sebesar 160 perkara atau mengalami penurunan sebesar 5,88\% dari tahun sebelumnya. Namun pada tahun 2016, terjadi kenaikan dari tahun sebelumnya sebesar 230 perkara atau mengalami kenaikan dari tahun sebelumnya sebesar 43,75\%. Adapun jumlah perkara yang 
telah diputus oleh Pengadilan Agama Klas I A dari jenis perkara cerai talak dalam rentang waktu 2013-2016 sebesar 690 perkara.

Adapun jenis perkara cerai gugat yang telah diputus oleh Pengadilan Agama Klas I A Palu pada tahun 2013 sebesar 402\ perkara. Kemudian pada tahun 2014 mengalami kenaikan sebesar 460 perkara atau mengalami kenaikan dari tahun sebelumnya sebesar $14,43 \%$. Kemudian pada tahun berikutnya yaitu tahun 2015 kembali mengalami kenaikan sebesar 486 perkara atau kenaikan terjadi hingga 5,65\% dari tahun sebelumnya. Selanjutnya pada tahun 2016 kembali mengalami kenaikan sebesar 573 perkara yang telah diputus atau kenaikan terjadi hingga 17,90\% dari tahun sebelumnya. Adapun jumlah perkara cerai gugat yang telah diputus oleh Pengadilan Agama Klas I A rentang waktu 2013-2016 sebesar 1.921 perkara.

Adapun jumlah perkara yang diterima secara keseluruhan baik dari jenis perkara cerai gugat dan cerai talak yang telah oleh Pengadilan Agama Klas I A Palu pada tahun 2013 berjumlah 531 perkara. Kemudian pada tahun berikutnya pada tahun 2014 mengalami kenaikan sebesar 630 perkara atau naik sebesar $18,42 \%$ dari tahun sebelumnya. Pada tahun selanjutnya yaitu 2015 kembali mengalami kenaikan sebesar 646 perkara atau naik sebesar 2,54\% dari tahun sebelumnya. Kemudian pada tahun 2016 kembali mengalami kenaikan dengan jumlah 803 perkara atau naik sebesar $24,30 \%$ dari tahun sebelumnya. Adapun jumlah keseruhan total jumlah perkara yang telah diputus oleh Pengadilan Agama Klas I A Palu baik jenis perkara cerai gugat dan cerai talak rentang waktu 20132016 sebesar 2.611 perkara.

Berdasarkan data di atas, maka dapat disimpulkan tingkat perceraian di Kota Palu senantiasa mengalami kenaikan dari tahun ke tahun. Hal ini tidak terlepas dari majemuknya masyarakat Kota Palu serta latar belakang hingga 
berbagai masalah perkotaan yang menjadi penyebab terjadinya kenaikan perceraian umat muslim di Kota Palu.

\section{B. Faktor-Faktor Penyebab Terjadinya Perceraian pada Masyarakat Muslim}

\section{Kota Palu}

Peramasalah yang timbul dalam rumah tangga dapat disebabkan karena adanya tekanan-tekakan dari pihak ketiga baik itu dari pihak keluarga istri atau suami, bisa juga dari pihak di luar hubungan keluarga ke duanya yang menyebabkan ketidak harmonisan di antara keduanya. Perselisihan dan kesalah pahaman di antara pasangan suami istri yang kerap terjadi dapat berdampak terhadap kelanggengan rumah tangga.

Adapun faktor penyebab perceraian umat muslim di Kota Palu terdiri atas beberapa hal, diantaranya adalah:

1. Poligami tidak sehat

2. Kritis akhlak

3. Zina

4. Mabuk

5. Judi

6. Meninggalkan salah satu pihak

7. Cacat badan

8. Cemburu

9. Kawin paksa

10. Ekonomi

11. Tidak ada tanggung jawab

12. Kekejaman jasmani/KDRT

13. Kekejaman mental

14. Dihukum 
15. Cacat biologis

16. Gangguan pihak ketiga

17. Tidak ada keharmonisan

Berdasarkan data 2014 yang dirilis oleh Pengadilan Agama Palu, faktorfaktor penyebab terjadinya perceraian dapat dilihat pada tabel di bawah ini:

Tabel 3.4

Faktor-faktor Penyebab Perceraian pada Pengadilan Agama Palu Tahun 2014

No Faktor-faktor Penyebab

Jumlah

1 Kritis Akhlak 68

2 Cemburu 34

3 Ekonomi 54

4 Tidak ada tanggung jawab 69

$5 \quad$ Kekejaman jasmani 38

$6 \quad$ Kekejaman mental 1

7 Dihukum 1

8 Cacat biologis 3

9 Gangguan pihak ketiga 128

10 Tidak ada keharmonisan 218

11 Lain-lain 4

$\begin{array}{ll}\text { Jumlah } & 618\end{array}$

Sumber: Pengadilan Agama Klas IA Palu, 2018

Berdasarkan data di atas ditemukan bahwa faktor-faktor penyebab terjadinya perceraian pada tahun 2014 adalah kritis akhlak sebanyak 68 kasus atau 11\%, faktor cemburu sebanyak 34 kasus atau 5,50\%, faktor ekonomi sebanyak 54 kasus atau 8,74\%, faktor tidak ada tanggung jawab sebanyak 69 kasus atau 11,17\%, 
faktor kekejaman jasmani sebanyak 38 kasus atau 6,15\%, faktor kekejaman mental sebanyak 1 kasus atau 0,16\%, faktor dihukum sebanyak 1 kasus atau 0,16\%, faktor cacat biologis sebanyak 3 kasus atau 0,49\%, ganggung pihak ketiga sebanyak 128 kasus atau 20,71\%, faktor tidak ada keharmonisan sebanyak 218 kasus atau 35,28\%, dan faktor lain-lain sebanyak 4 kasus atau 0,65\%.

Dari data tersebut ditemukan bahwa faktor penyebab terjadinya perceraian pada tahun 2014 adalah tidak ada keharmonisan (35,28\%), gangguan pihak ketiga (20,71\%), tidak ada tanggung jawab (11,17\%), kritis akhlak (11\%), ekonomi $(8,74 \%)$.

Selanjutnya faktor-faktor penyebab terjadinya perceraian pada tahun 2015 adalah sebagai berikut:

\section{Tabel 4.4}

Faktor-faktor Penyebab Perceraian pada Pengadilan Agama Palu Tahun 2015

\section{No Faktor-faktor Penyebab}

1 Krisis akhlak

\section{Jumlah}

2 Cemburu

3 Ekonomi

4 Tidak ada tanggung jawab

$5 \quad$ Kekejaman jasmani

6 Dihukum 58

7 Cacat biologis

8 Ganggung pihak ketiga

9 Tidak ada keharmonisan

Jumlah

Sumber: Pengadilan Agama Klas IA Palu, 2018

Berdasarkan data di atas ditemukan bahwa faktor-faktor penyebab terjadinya perceraian pada tahun 2015 adalah krisis akhlak sebanyak 34 kasus atau 
$5,46 \%$, cemburu sebanyak 30 kasus atau 4,82\%, ekonomi sebanyak 55 kasus atau 8,83, tidak ada tanggung jawab sebanyak 107 kasus atau 17,17\%, kekejaman jasmani sebanyak 58 kasus atau 9,31\%, dihukum sebanyak 1 kasus atau 0,16\%, cacat biologis sebanyak 2 kasus atau 0,32\%, gangguan pihak ketiga sebanyak $18,46 \%$, dan tidak keharminisan sebanyak 221 kasus atau 35,47\%.

Dari hasil di atas, maka dapat disimpulkan bahwa faktor tidak keharmonisan penyebab terbesar terjadinya perceraian dengan jumlah 221 kasus atau $35,47 \%$ dari seluruh kasus yang perceraian terjadi. Kemudian dilanjutkan oleh gangguan pihak ketiga dengan persentase $18,46 \%$, dam diikuti oleh tidak ada tanggung jawab dengan persentase sebanyak $17,17 \%$.

Selanjutnya faktor-faktor penyebab terjadinya perceraian pada tahun 2016 adalah sebagai berikut:

Tabel 4.4

Faktor-faktor Penyebab Perceraian pada Pengadilan Agama Palu Tahun 2016

No Faktor-faktor Penyebab

\section{Jumlah}

1 Poligami tidak sehat

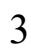

2 Krisis akhlak 15

3 Zina

1

4 Mabuk

9

5 Judi

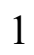

6 Meninggalkan salah satu pihak 74

7 Dihukum penjara

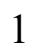

8 Cemburu 15

9 Tidak ada tanggung jawab 56

10 Kekejaman jasmani 92

11 Cacat badan 1

12 Gangguan pihak ketiga 
13 Tidak ada keharmonisan 97

14 Perilaku dan pertengkaran terus menerus 201

15 Kawin paksa 2

16 Murtad 6

17 Ekonomi 21

Jumlah 653

Sumber: Pengadilan Agama Klas IA Palu, 2018

Dari data di atas maka ditemukan penyebab terjadinya perceraian di Pengadilan Agama Klas IA Palu diantaranya adalah faktor poligami tidak sehat sebanyak 3 kasus, krisis akhlak sebanyak 15 kasus, zina sebanyak 1 kasus, mabuk sebanyak 9 kasus, judi sebanyak 1 kasus, meninggalkan salah satu pihak 74 kasus, dihukum penjara sebanyak 1 kasus, cemburu sebanyak 15 kasus, tidak ada tanggung jawab sebanyak 56 kasus, kekejaman jasmani sebanyak 92 kasus, cacat badan sebanyak 1 kasus, gangguan pihak ketiga sebanyak 58 kasus, tidak ada keharmonisan sebanyak 97 kasus, perilaku dan pertengkaran terus menerus sebanyak 201 kasus, kawin paksa sebanyak 2 kasus, murtad sebanyak 6 kasus, dan ekonomi sebanyak 21 kasus.

Dari data tersebut pula bahwa faktor penyebab terjadinya perceraian pada tahun 2016 yaitu perilaku dan pertengkaran terus menerus sebanyak 201 kasus dengan persentase 30,78\% dari seluruh kasus perceraian. Kemudian diikuti oleh tidak ada keharmonisan dengan persentase 14,85\%, lalu kekejaman jasmani dengan persentase $14,09 \%$, dan meninggalkan salah satu pihak dengan persentase $11,33 \%$.

Selanjutnya faktor-faktor penyebab terjadinya perceraian pada tahun 2016 adalah sebagai berikut:

Tabel 5.4

Faktor-faktor Penyebab Perceraian pada Pengadilan Agama Palu

Tahun 2017 
No

Faktor-faktor Penyebab

1 Zina

2 Mabuk

3 Madat

4 Judi

5 Meninggalkan salah satu pihak

6 Dihukum penjara

7 Poligami

8 KDRT

9 Perselisihan dan pertengkaran terus menerus

10 Kawin paksa

11 Murtad

12 Ekonomi

Jumlah

\section{Jumlah}

2

12

3

5

213

4

13

71

297

3

7

35

665

Sumber: Pengadilan Agama Klas IA Palu, 2018

Dari data di atas ditemukan bahwa faktor penyebab terjadi perceraian pada tahun 2017 yaitu zina sebanyak 2 kasus, mabuk sebanyak 12 kasus, madat sebanyak 3 kasus, judi sebanyak 5 kasusu, meninggalkan salah satu pihak 213 kasus, dihukum penjara sebanyak 4 kasus, poligami sebanyak 4 kasus, poligami sebanyak 13 kasus, KDRT sebanyak 71 kasus, perselisihan dan pertengkaran terus menerus sebanyak 297 kasus, kawin paksa sebanyak 3 kasus, murtad sebanyak 7 kasus, dan ekonomi sebanyak 35 kasus.

Dari data tersebut pula ditemukan bahwa faktor penyebab terjadinya perceraian pada tahun 2017 yaitu perselisihan dan pertengkaran terus menerus dengan persentase $44,66 \%$ dari jumlah persentase keseluruhan kasus, diikkuti oleh meninggalkan salah satu pihak sebanyak 32,03\%, dan KDRT dengan persentase sebensar $10,68 \%$. 
Berdasarkan data keseluruhan di atas yaitu faktor-faktor penyebab perceraian di Pengadilan Agama Palu rentang waktu 2014-2017, maka penyebab terbesar adalah faktor tidak ada keharmonisan dengan jumlah kasus sebanyak 536 kasus, kemudian faktor perselisihan dan pertengkaran terus menerus sebanyak 498 kasus, lalu gangguan pihak ketiga sebanyak 301 kasus, dan faktor meninggalkan salah satu pihak sebanyak 287 kasus.

\section{Solusi Mengatasi Terjadinya Peningkatan Perceraian pada Masyarakat Muslim Kota Palu}

Secara umum, masyarakat masih memandang negatif terhadap pasangan yang memutuskan bercerai. Bagi masyarakat, perceraian merupakan suatu hal yang buruk dan jahat, serta melukai perasaan salah satu pasangan dan berdampak tidak baik bagi anak dan keluarga kedua belah pihak. Perceraian yang diinginkan istri atau gugat cerai terhadap suami bahkan dipandang lebih buruk lagi dibanding talak yang dijatuhkan suami terhadap istri. Hal ini terjadi karena tradisi dan keyakinan masyarakat, posisi suami lebih tinggi derajatnya secara agama dan kultural dibandingkan istri.

Sebelumnya jarang ada kasus istri menggugat cerai suaminya seperti yang marak terjadi belakangan ini. Paradigma negatif terhadap perceraian juga tidak terlepas dari pemahaman umum masyarakat yang menganggap bahwa perkawinan sebagai sebuah peristiwa sakral yang dilakukan di bawah otoritas agama dan pemerintah. Perkawinan tidak hanya melibatkan calon suami dan istri, tetapi juga melibatkan kerabat dekat, keluarga besar, masyarakat, pemangku adat dan agama. Oleh karenanya, perkawinan yang berakhir dengan perceraian dinilai tidak hanya melecehkan keluarga, tapi juga melecehkan masyarakat, adat dan agama.

Pada posisi ini, kecaman terhadap pasangan yang bercerai bisa dipahami karena perkawinan masuk dalam wilayah sakral serta melibatkan semua pihak. 
Proses dan tradisi perkawinan juga terbilang ketat di Indonesia, menghabiskan banyak energi dan biaya yang tidak sedikit. Dari segi dampak, perceraian juga berdampak luas. Selain berdampak psikis terhadap anak dan keluarga, perceraian juga berdampak terhadap rusaknya tatanan sosial, serta memberi contoh tidak baik bagi pasangan lain, dan seolah-olah perceraian satu-satunya jalan ketika keluarga dihadapkan pada masalah dalam rumah tangga.

Apalagi bagi masyarakat tradisional dimana pembagian peran dalam rumah tangga belum berimbang, suami dinobatkan sebagai kepala rumah tangga atau pencari nafkah (aktif), sementara istri sebagai ibu rumah tangga (pasif). Bila hal ini terjadi perceraian, mata rantai ekonomi keluarga akan terputus dan disimpulkan bahwa paradigma masyarakat terhadap perceraian cenderung di bangun atas dasar keyakinan, pengalaman dan realitas.

Faktor dominan penyebab perceraian di Kota Palu dikarenakan perselisihan dan pertengkaran terus menerus. Hal ini terjadi tatkala dua insan yang disatukan dalam ikatan pernikahan yang dalam perjalanannya ternyata ada ketidakcocokan diantaranya sehingga menimbulkan pertengkaran yang berkepanjangan, hingga akhirnya keduanya sepakat untuk berpisah dan mengakhiri hubungan.

Setelah pernikahan berlangsung, pasangan suami istri diberikan pengetahuan maupun pelatihan untuk memperkuat pernikahannya dan serta cara mengatasi permasalahan yang ditemui dalam proses penyesuaian dengan pasangan. Menurut Hilal Malarangan, dewasa ini telah banyak pengetahuan terkait membina rumah tangga melalui berbagai media sosial yang memberikan pemahaman kepada para pembaca dan pengguna media sosial sehingga memberikan kesadaran kepada pasangan suami istri terkait hak dan kewajiban 
masing-masing. ${ }^{25}$ Selain itu, terdapat pula berbagai pelatihan dan kuliah yang menggunakan media sosial seperti whatsupp sebagai wadah bagi pasangan suami istri menanyakan hal-hal terkait dengan permasalahan anak, ekonomi, hingga kepada kehidupan sosial di tengah-tengah masyarakat.

Pada saat pasangan berniat untuk bercerai, maka perlu dilakukan mediasi di antara kedua belah pihak melalui lembaga penasehat perkawinan maupun konselor pernikahan. Upaya mediasi ini bertujuan untuk mencegah terjadinya perceraian sebelum perkara diajukan pada pengadilan agama. Namun, apabila perceraian terjadi, hendaknya pasangan mendapatkan pendampingan dalam mempersiapkan diri menghadapi perceraian. ${ }^{26}$ Pada tahap ini pula sebaiknya pasangan suami istri melakukan musyawarah dan melibatkan orang-orang terdekat sehingga perceraian tidak terjadi. Pencekatan secara kekeluargaan melalui orang tua dan keluarga dekat. Namun terkadang pula pendekatan kekeluargaan malah menambah persoalan baru utamanya pada persidangan.

Setelah perceraian terjadi, pasangan yang bercerai seringkali kesulitan untuk menyesuaikan diri dengan perannya yang baru. Hal ini juga dapat mempengaruhi kesehatan mental mereka sehingga tampaknya diperlukan upaya dalam memulihkan kondisi pasangan cerai tersebut. ${ }^{27}$

Selain hal di atas, pemerintah telah mengeluarkan kebijakan Peraturan Mahkamah Agung RI No. 01 Tahun 2008 tentang Prosedur Mediasi di Pengadilan yang kemudian disempurnakan dengan terbitnya Peraturan Mahkamah Agung RI (PERMA) No.1 Tahun 2016 tentang Prosedur Mediasi di Pengadilan.

${ }^{25}$ Hilal Malarangan, Tokoh Masyarakat, Wawancara, Palu, 7 Juli 2018.

${ }^{26}$ Yunita Sari, Penanggulangan Perceraian dan Kesiapan Menikahi Orang yang Berbeda, https://www.unisba.ac.id/index.php/id/printing/item/302-penanggulangan-perceraian-dankesiapan-menikahi-orang-yang-berbeda, (2 Juli 2018)

${ }^{27}$ Ibid. 
PERMA No. 1 Tahun 2016 Tentang Prosedur Mediasi di Pengadilan ini ditetapkan di Jakarta pada tanggal 3 Februari 2016 dan mulai diundangkan pada tanggal 4 Februari 2016. PERMA ini dimuat dalam Berita Negara Republik Indonesia Tahun 2016 Nomor 175. Sebagaimana diterangkan di bagian awal dan dalam Pasal 39, PERMA No. 1 Tahun 2016 ditetapkan guna mengganti ketentuan-ketentuan mediasi yang ada dalam PERMA No. 1 Tahun 2008 yang dinilai masih belum optimal dalam hal memenuhi kebutuhan pelaksanaan mediasi yang lebih berdaya guna.

Beberapa perubahan dengan terbitnya PERMA tersebut diantaranya adalah Pertama, terkait batas waktu mediasi yang lebih singkat dari 40 hari menjadi 30 hari terhitung sejak penetapan perintah melakukan Mediasi. Kedua, adanya kewajiban bagi para pihak (inpersoon) untuk menghadiri secara langsung pertemuan Mediasi dengan atau tanpa didampingi oleh kuasa hukum, kecuali ada alasan sah seperti kondisi kesehatan yang tidak memungkinkan hadir dalam pertemuan Mediasi berdasarkan surat keterangan dokter; di bawah pengampuan; mempunyai tempat tinggal, kediaman atau kedudukan di luar negeri; atau menjalankan tugas negara, tuntutan profesi atau pekerjaan yang tidak dapat ditinggalkan. ${ }^{28}$

Ketiga, hal yang paling baru adalah adanya aturan tentang Iktikad Baik dalam proses mediasi dan akibat hukum para pihak yang tidak beriktikad baik dalam proses mediasi. Pasal 7 menyatakan: (1) Para Pihak dan/atau kuasa hukumnya wajib menempuh Mediasi dengan iktikad baik. 2) Salah satu pihak atau Para Pihak dan/atau kuasa hukumnya dapat dinyatakan tidak beriktikad baik oleh Mediator dalam hal yang bersangkutan:

${ }^{28}$ Abd. Pakih, Hakim Pengadilan Agama Klas IA Palu, Wawancara, Palu 4 Juli 2018. 
1. tidak hadir setelah dipanggil secara patut 2 (dua) kali berturut-turut dalam pertemuan Mediasi tanpa alasan sah;

2. menghadiri pertemuan Mediasi pertama, tetapi tidak pernah hadir pada pertemuan berikutnya meskipun telah dipanggil secara patut 2 (dua) kali berturut-turut tanpa alasan sah;

3. ketidakhadiran berulang-ulang yang mengganggu jadwal pertemuan Mediasi tanpa alasan sah;

4. menghadiri pertemuan Mediasi, tetapi tidak mengajukan dan/atau tidak menanggapi Resume Perkara pihak lain; dan/atau

5. tidak menandatangani konsep Kesepakatan Perdamaian yang telah disepakati tanpa alasan sah. ${ }^{29}$

Thalis menjelaskan, apabila penggugat dinyatakan tidak beriktikad baik dalam proses Mediasi sebagaimana dimaksud dalam Pasal 7 ayat (2), maka berdasarkan Pasal 23, gugatan dinyatakan tidak dapat diterima oleh Hakim Pemeriksa Perkara. Hal ini ditegaskan dalam Pasal 22 PERMA No.1 Tahun 2016. Penggugat yang dinyatakan tidak beriktikad baik sebagaimana dimaksud pada ayat (1) dikenai pula kewajiban pembayaran Biaya Mediasi. Mediator menyampaikan laporan penggugat tidak beriktikad baik kepada Hakim Pemeriksa Perkara disertai rekomendasi pengenaan Biaya Mediasi dan perhitungan besarannya dalam laporan ketidakberhasilan atau tidak dapat dilaksanakannya Mediasi.

Berdasarkan laporan Mediator sebagaimana dimaksud pada ayat (3), Hakim Pemeriksa Perkara mengeluarkan putusan yang merupakan putusan akhir yang menyatakan gugatan tidak dapat diterima disertai penghukuman pembayaran Biaya Mediasi dan biaya perkara.

${ }^{29}$ Suhri Hanafi, Tokoh Masyarakat, Wawancara, Palu, 9 Juli 2018 
Biaya Mediasi sebagai penghukuman kepada penggugat dapat diambil dari panjar biaya perkara atau pembayaran tersendiri oleh penggugat dan diserahkan kepada tergugat melalui kepaniteraan Pengadilan. Apabila Tergugat yang dinyatakan tidak beriktikad baik sebagaimana dimaksud dalam Pasal 7 ayat (2), dikenai kewajiban pembayaran Biaya Mediasi. Mediator menyampaikan laporan tergugat tidak beriktikad baik kepada Hakim Pemeriksa Perkara disertai rekomendasi pengenaan Biaya Mediasi dan perhitungan besarannya dalam laporan ketidakberhasilan atau tidak dapat dilaksanakannya Mediasi.

Berdasarkan laporan Mediator sebagaimana dimaksud pada ayat (2), sebelum melanjutkan pemeriksaan, Hakim Pemeriksa Perkara dalam persidangan yang ditetapkan berikutnya wajib mengeluarkan penetapan yang menyatakan tergugat tidak beriktikad baik dan menghukum tergugat untuk membayar Biaya Mediasi.

Pada dasarnya muncul mediasi secara resmi dilatarbelakangi adanya realitas sosial pada pengadilan sebagai satu lembaga penyelesaian perkara dipandang belum mampu menyelesaikan perkaranya sesuai dengan harapan masyarakat. Kritik terhadap lembaga peradilan disebabkan karena banyak faktor, antara lain penyelesaian jalur litigasi pada umumnya lambat (waste of time), pemeriksaan sangat formal (folrmalistic), sangat teknis (technically), dan perkara yang masuk pengadilan sudah overloaded. Di samping itu, keputusan pengadilan selalu diakhiri dengan menang dan kalah, maka kepastian hukum dipandang merugikan salah satu pihak berperkara. Hal ini berbeda jika penyelesaian perkara melalui jalur mediasi, maka kemauan para pihak dapat terpenuhi meskipun tidak sepenuhnya. Penyelesaian ini mengedepankan kepentingan dua pihak sehingga putusannya bersifat win-win solution ${ }^{30}$.

\footnotetext{
${ }^{30}$ Lihat Muhammad Saifullah, "Sejarah dan Perkembangan Mediasi di Indonesia" www.badilag.net. (06 Februari 2010), h. 2.
} 
Kehadiran PERMA dimaksudkan untuk memberikan kepastian, ketertiban, kelancaran dalam proses mendamaikan para pihak untuk menyelesaikan sengketa perkara perdata. Hal ini dapat dilakukan dengan mengintensifkan dan mengintegrasikan proses mediasi ke dalam prosedur perkara di pengadilan. Mediasi mendapat kedudukan penting dalam Perma karena proses mediasi merupakan bagian yang tidak terpisahkan dari proses perkara di pengadilan. Hakim wajib mengikuti prosedur penyelesaian sengketa melalui mediasi. Bila hakim melanggar atau enggan menggunakan proses mediasi, maka putusan hakim batal demi hukum.

C. Penutup

\section{Kesimpuan}

Berdasarkan hasil penelitian yang penulis lakukan pada Pengadilan Agama Klas IA Palu, penulis akan kemukakan kesimpulan sebagai berikut:

1. Tingkat perceraian di Kota Palu senantiasa mengalami kenaikan dari tahun ke tahun. Hal ini tidak terlepas dari majemuknya masyarakat Kota Palu serta latar belakang hingga berbagai masalah perkotaan yang menjadi penyebab meningkatnya angka perceraian umat muslim di Kota Palu.

2. Faktor-faktor penyebab perceraian di Pengadilan Agama Palu rentang waktu 2014-2017, maka penyebab terbesar adalah faktor tidak ada keharmonisan dengan jumlah kasus sebanyak 536 kasus, kemudian faktor perselisihan dan pertengkaran terus menerus sebanyak 498 kasus, lalu gangguan pihak ketiga sebanyak 301 kasus, dan faktor meninggalkan salah satu pihak sebanyak 287 kasus.

3. Solusi mengatasi peningkatan terjadinya perceraian yaitu dapat dilakukan melalui fase sebelum pernikahan, setelah pernikahan, saat pasangan berniat untuk bercerai, dan setelah perceraian terjadi. Selain itu dapat pula 
melalui mediasi yang telah ditetapkan melalui Peraturan Mahkamah Agung Nomor 1 Tahun 2016.

\section{DAFTAR PUSTAKA}

Abidin, Slamet dan Aminuddin. Fiqih Munakahat 1. Bandung: Pustaka Setia, 1999

Ad-Dimasyqi, Muhammad bin Abdurrahman. Rahmah al-Ummah fi Ikhtilaf alA'immah (Fikih Empat Madzhab). alih bahasa Abdullah Zaki Alkaf, Bandung: Hasyimi Press, 2004.

Al-Istanbūli, Muhammad Mahdi. Tah̆fas al-A'rūs, terj. Ibnu Ibrahim, Kado Perkawinan. Cet. I; t.t.: Pustaka Azzam, 1999.

As-Subki, Ali Yusuf. Fiqh Keluarga Pedoman Berkeluarga Dalam Islam. Jakarta: Amzah, 2010.

Bungin, Burhan. Penelitian Kualitatif. Jakarta: Kencana, 2009.

Departemen Agama RI. Al-Qur'an Al-Karim dan Terjemahnya. Semarang; PT. Karya Toha Putra Semarang, 2002.

Malik, Vijai. Muslim Law of Marriage, Divorce and Mainternance. Delhi: Eastern Book Company, 1988.

Moleong, Lexy J. Metodelogi Penelitian Kualitatif. Bandung: Remaja Rosdakarya, 2009.

Muhammad Mustafā Tsalabì, Ahkām al-Usrah fī al-Islam, (Beirut: Dār an-Naḍah al-'Arabiyah, 1997), h. 260.

Muhammad, Abdul Kadir. Hukum dan Penelitian Hukum. Bandung: PT. Citra Aditya Bakti, 2004.

Rasyid, Harun. Metode Penelitian Kualitatif Bidang Ilmu Sosial dan Agama. Pontianak: STAIN Pontianak, 2000.

Rasyid, Sulaiman. Fiqh Islam. Cet. VII; Bandung: Sinar Baru Algensindo, 1994..

Sābiq, Sayyid. Fiqh al-Sunnah, Juz. II. t.t.: Dār Šiqāfah Islāmiyyah, t.th.

Shihab, M. Quraish Shihab. Pengantin Al-Qur'an Kalung Permata Buat Anakanakku. Cet. VI; Jakarta: Lentera Hati, 2007.

Sugiyono. Memahami Penelitian Kualitatif. Bandung: Alfabeta, 2008. 
Sugiyono. Metode Penelitian Kuantitatif Kualitatif dan $R \& D$. Cet. VI; Bandung: Alfabeta, 2009

Syaifuddin, Muhammad dkk. Hukum Perceraian. Jakarta: Sinar Grafika, 2014.

Syarifuddin, Amir. Hukum Perkawinan Islam di Indonesia. Jakarta: Prenada Media, 2006.

Usman, Husaini. Purnomo Setiady Akbar. Metodologi Penelitian Sosial. Cet. IV; Jakarta: Bumi Aksara, 20031.

Ritzer, George. Sosiologi Ilmu Pengetahuan Beparadigma Ganda, Cet. 10; Jakarta: Raja Grafindo, 2013.

Ritzer, George. Teori Sosiologi Modern. Cet.VIII; Jakarta: Bumi Aksara, 2010.

Goode, J.William. Sosiologi Keluarga. Jakarta: Bumi Aksara, 2004.

Soekanto, Soejono. Sosiologi Keluarga; Tentang Ikhwal Keluarga, Remaja dan Anakia. Jakarta; Rineka Cipta, 2004.

Azzam, Abdul Aziz M \& Abdul Wahhab Sayyed Hawwas. 2009. Fiqh Munakahat

(Khitbah, Nikah, dan Talak). Jakarta: Amzah. Basyir, Ahmad Azhar. 2000. Hukum Perkawinan Islam. Yogyakarta: UII Press.

Dwi Purnawan, "Tingkat Percerain Termasuk yang Tertinggi di Dunia" http://www.gulalives.co/2016/09/26/tingkat-perceraian-di-indonesiatermasuk-yang-tertinggi-di-dunia/, 26 September 2016 diakses pada tanggal 15 Oktober 2017.

Republika, "Tingkat Perceraian Mengkhawatirkan", http://www.republika.co.id/berita/koran/halaman-1/16/10/03/oegjc619tingkat-perceraian-mengkhawatirkan, 3 Oktober 2016 diakses pada pada tanggal 15 Oktober 2017.

Republika, Angka Perceraian di Sulteng Capai 2.699 Kasus Selama 2016" http://nasional.republika.co.id/berita/nasional/daerah/17/02/01/okpa5x384 -angka-perceraian-capai-2699-kasus-di-sulteng-selama-2016, 1 Februari 2017 diakses pada tanggal 15 Oktober 2017.

Wikipedia, "Kota Palu” https://id.wikipedia.org/wiki/Kota_Palu, 16 Oktober 2017. 